\title{
Review \\ The Role of E3s in Regulating Pluripotency of Embryonic Stem Cells and Induced Pluripotent Stem Cells
}

\author{
Yahong Wu and Weiwei Zhang * \\ College of Life Sciences, Capital Normal University, Beijing 100048, China; 17835061377@163.com \\ * Correspondence: zhangww@cnu.edu.cn; Tel.: +86-10-68901494
}

Citation: Wu, Y.; Zhang, W. The Role of E3s in Regulating Pluripotency of Embryonic Stem Cells and Induced Pluripotent Stem Cells. Int. J. Mol. Sci. 2021, 22, 1168. https://doi.org/ 10.3390/ijms22031168

Academic Editor:

Suresh Ramakrishna

Received: 25 December 2020

Accepted: 20 January 2021

Published: 25 January 2021

Publisher's Note: MDPI stays neutral with regard to jurisdictional claims in published maps and institutional affiliations.

Copyright: (c) 2021 by the authors. Licensee MDPI, Basel, Switzerland. This article is an open access article distributed under the terms and conditions of the Creative Commons Attribution (CC BY) license (https:// creativecommons.org/licenses/by/ $4.0 /)$.

\begin{abstract}
Pluripotent embryonic stem cells (ESCs) are derived from early embryos and can differentiate into any type of cells in living organisms. Induced pluripotent stem cells (iPSCs) resemble ESCs, both of which serve as excellent sources to study early embryonic development and realize cell replacement therapies for age-related degenerative diseases and other cell dysfunction-related illnesses. To achieve these valuable applications, comprehensively understanding of the mechanisms underlying pluripotency maintenance and acquisition is critical. Ubiquitination modifies proteins with Ubiquitin $(\mathrm{Ub})$ at the post-translational level to monitor protein stability and activity. It is extensively involved in pluripotency-specific regulatory networks in ESCs and iPSCs. Ubiquitination is achieved by sequential actions of the $\mathrm{Ub}$-activating enzyme $\mathrm{E} 1, \mathrm{Ub}$-conjugating enzyme $\mathrm{E} 2$, and $\mathrm{Ub}$ ligase E3. Compared with E1s and E2s, E3s are most abundant, responsible for substrate selectivity and functional diversity. In this review, we focus on E3 ligases to discuss recent progresses in understanding how they regulate pluripotency and somatic cell reprogramming through ubiquitinating core ESC regulators.
\end{abstract}

Keywords: ubiquitination; pluripotency; embryonic stem cells; induced pluripotent stem cells

In culture, embryonic stem cells (ESCs) can indefinitely self-renew while maintaining pluripotency [1]. These capabilities are attributed to the unique regulatory network that governs the ESC-specific gene expression profile and chromatin landscape. The factors anchored in the network include transcription factors (TFs), RNA molecules, and epigenetic regulators [2,3]. Particularly, Octamer-binding transcription factor-4 (Oct4), sex-determining region Y (SRY)-related high-mobility-group (HMG) Box 2 (Sox2), and Nanog form the core transcriptional regulatory circuitry governing pluripotency maintenance and acquisition [4-6]. How to maintain the precise levels of these core regulators is fundamental for their pivotal activity in ESC maintenance and pluripotency induction. Transcriptomic and proteomic analysis suggest extensive involvement of ubiquitination in pluripotency regulation [7-10]. In this review, we summarize the progress in understanding ubiquitination-mediated regulation of pluripotency maintenance and acquisition, and mainly discuss how E3s recognize and fine-tune the expressions and activity of core pluripotency regulators so as to achieve pluripotency maintenance and reinstatement.

\section{Pluripotent Cells}

Embryonic development starts from the totipotent zygote. At the blastocyst stage, embryonic cells are diverged into the inner cell mass (ICM) and the external mono-layer trophectoderm [11]. The ICM cells are pluripotent since they can give rise to all three embryonic germ layers (ectoderm, endoderm, and mesoderm), but fail in forming a complete embryo alone [12]. Pluripotency is preserved by the epiblast cells that act as sources of all specialized progeny cells in living organisms [13]. Interestingly, the transient pluripotency of early embryonic cells can be represented by cultivated cells in vitro (Figure 1). Embryonal carcinoma (EC) cells are the first pluripotent cell type grown in culture. However, their application potential is limited because they are derived from teratomas/teratocarcinomas and usually abnormal in chromosomes [14-22]. The first 
"true" embryo-derived pluripotent cells are ESCs established by Martin Evans, Matthew Kaufman and Gail Martin [23,24]. ESCs can be isolated from the ICM or the epiblast of the mature blastocyst $[23,24]$. Interestingly, although embryos gradually lose pluripotency upon proceeding into the gastrulation stage, researchers isolate pluripotent epiblast stem cells (EpiSCs) from the post-implantation epiblast tissues $[25,26]$. Of note, ESCs and EpiSCs display two different pluripotent states. EpiSCs are primed pluripotent since they are deficient in chimera formation, though they can differentiate into all three germ lineages [26]. ESCs faithfully capture the naïve pluripotency resembling the in vivo ICM and epiblast of the blastocyst in the serum-free medium supplemented with two inhibitors (2i), PD0325901 and CHIR99021, respectively, inhibiting the Mek/Erk and Gsk3 activity [27]. They maintain superior differentiation capability and can consistently produce germline chimeras with normal diploid karyotype $[4,12,13,28]$. Thus, ESCs serve as an excellent model to study embryogenesis and perform cell replacement therapies. To date, ESCs have been successfully isolated and cultivated from various species, such as mice, humans, non-human primates, and pigs $[23,29,30]$. Embryonic origin of ESCs ineluctably brings about the ethical concerns surrounding ESC research. However, that has been alleviated by the seminal work of Takahashi and Yamanaka. The duo elegantly restored pluripotency through the introduction of defined factors in mouse somatic cells to generate induced pluripotent stem cells (iPSCs) [31]. Human iPSCs were derived soon afterwards [32-34]. iPSCs possess similar differentiation capacity with ESCs, and thus allow us to generate patient-specific pluripotent cells for cell therapy of degenerative and other human diseases.

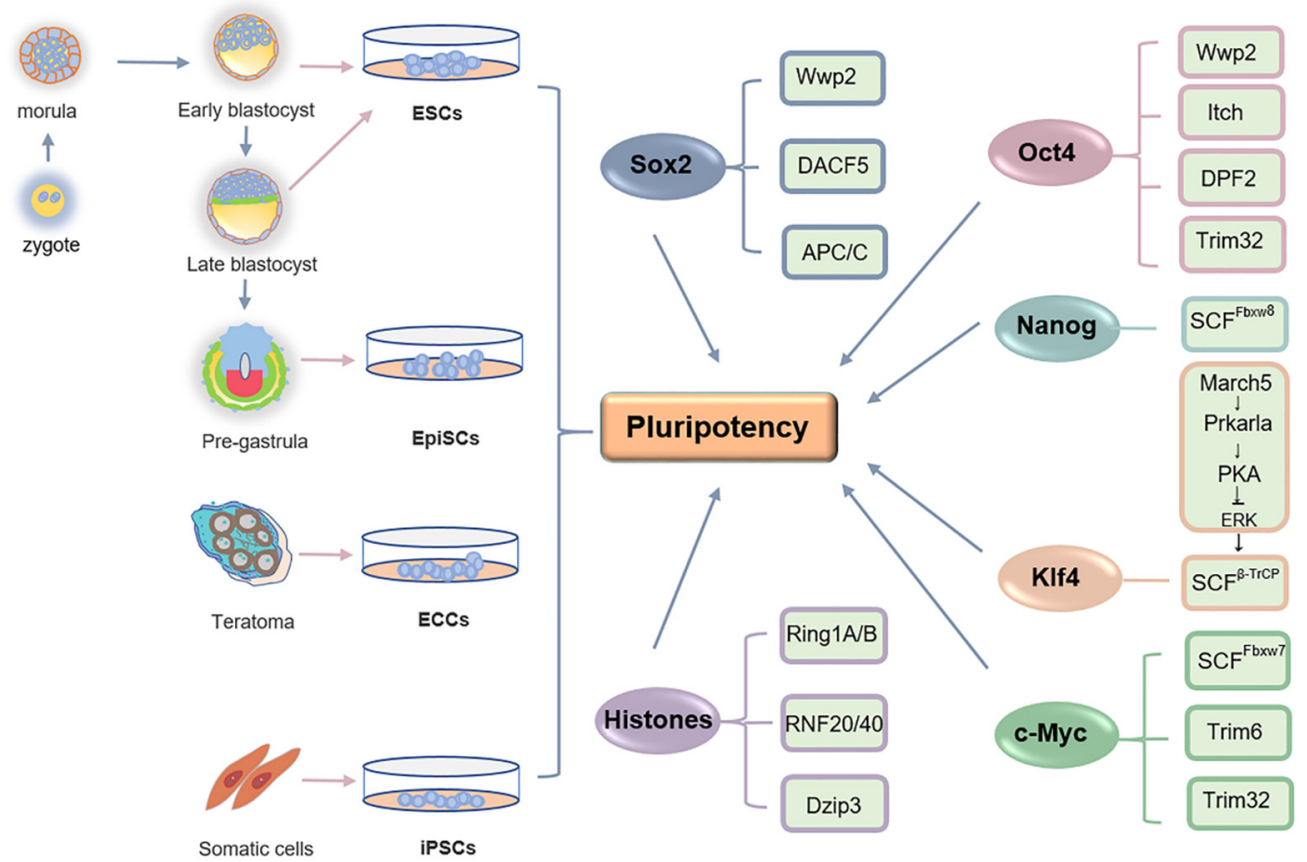

Figure 1. E3s are involved in regulating pluripotency. Pluripotent cells can be derived from teratomas or early embryos. Pluripotency can also be restored through introducing defined factors in somatic cells to generate iPSCs. Multiple E3s have been identified for their critical roles in monitoring the stability or activity of pluripotency regulators.

\section{Ubiquitination}

Ubiquitination is a fundamental process post-translationally modifying proteins with a single $\mathrm{Ub}$ (monoubiquitination) or a poly- $\mathrm{Ub}$ chain (polyubiquitination) to regulate protein stability or activity $[35,36]$. $\mathrm{Ub}$ is a small-sized protein comprising only 76 amino acids and highly conserved among all types of eukaryotic cells [37-39]. In most cases, the C-terminal glycine $76 \mathrm{Of} \mathrm{Ub}(\mathrm{Ub}-\mathrm{G} 76)$ is conjugated to an internal lysine $(\mathrm{K})$ residue of substrates via an isopeptide bond. However, some non-K residues of proteins, such as methionine-1 (M1), cysteine $(\mathrm{C})$, serine $(\mathrm{S})$, threonine $(\mathrm{T})$ and tyrosine $(\mathrm{Y})$, can serve as ubiquitination sites 
under some particular conditions [40-44]. To form a poly-Ub chain, the Ub-G76 of a distal $\mathrm{Ub}$ is covalently connected with one $\mathrm{K}$ residue of a proximal $\mathrm{Ub}$. $\mathrm{Ub}$ harbors seven $\mathrm{Ks}$ in total, respectively, K6, K11, K27, K29, K33, K48, and K63. Any of these residues can be employed for poly-Ub chain assembly [45]. Alternatively, the G76 residue of the proximal $\mathrm{Ub}$ can connect with the $\mathrm{M} 1$ of the distal $\mathrm{Ub}$ to form a linear poly-Ub chain [46]. What is more, poly-Ub chains can be homotypic, or heterotypic (mixed or branched) comprising multiple linkage types, such as K11/K48-branched chains, K48/K63-branched chains, and K63/M1-linked hybrid linkage [47-49] (Figure 2).

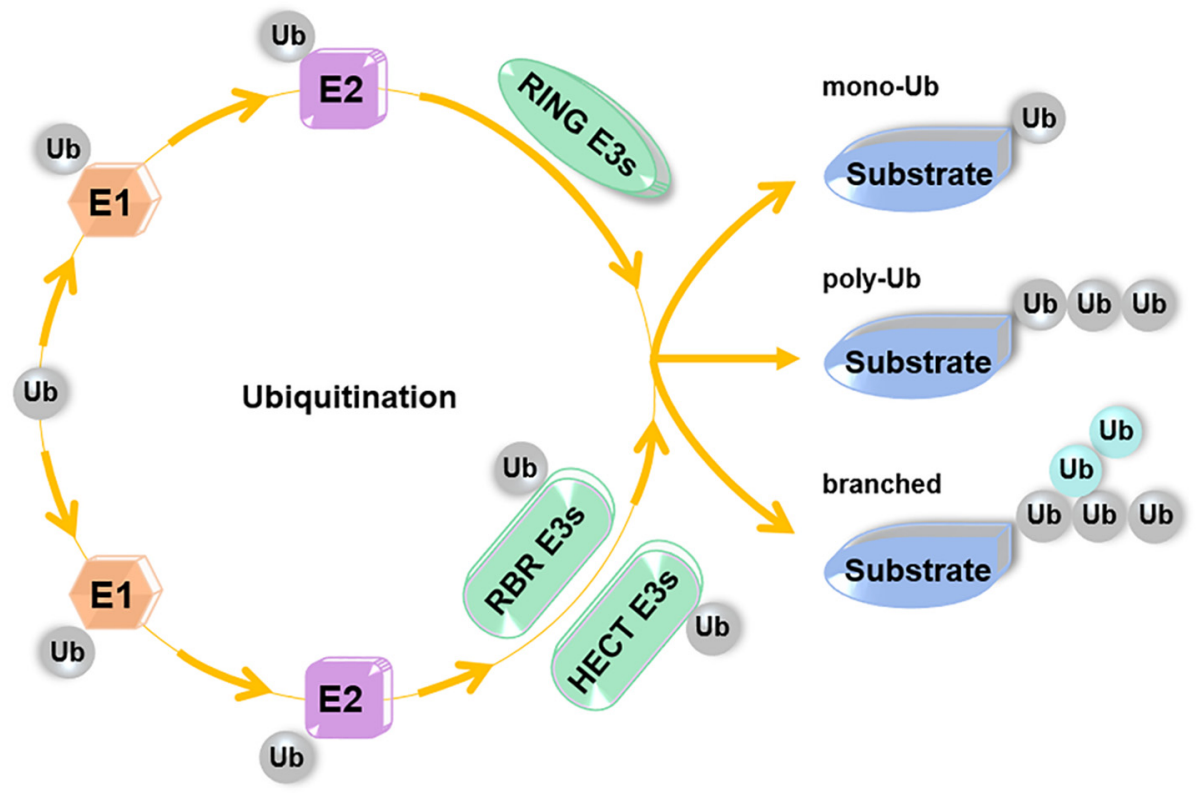

Figure 2. The process of ubiquitination. E1 activates $\mathrm{Ub}$ to form the E1-Ub intermediate. Next, E2 catalyzes transthiolation reaction to transfer $\mathrm{Ub}$ from the $\mathrm{E} 1-\mathrm{Ub}$ complex to its active $\mathrm{C}$ site. An E3 ligase is responsible for the final reaction. RING-type E3s facilitate direct Ub transfer from E2s to substrates, whereas HECT-type and RBR-type E3s adopt two-step reactions for Ub conjugation. Substrate proteins can be modified by mono-ub or poly-ub chains. A poly-Ub chain can be homotypic with only one linkage type or heterotypic with mixed or branched linkages.

In general, ubiquitination is achieved by three continuous catalytic reactions (Figure 2). The Ub-activating enzyme (Uba, E1) firstly initiates the conjugation process. It adenylates $\mathrm{Ub}-\mathrm{G} 76$ in an ATP hydrolysis-dependent manner to form a Ub-adenosine monophosphate $(\mathrm{Ub}-\mathrm{AMP})$ intermediate. The intermediate subsequently accesses the E1 active cysteine (C) site via nucleophilic attack. A thioester bond is formed connecting the E1 with Ub-G76, accompanied with AMP release [50]. The second reaction is mediated by a Ub-conjugating enzyme (UBC, E2). E2 catalyzes transthiolation reaction, in which the $\mathrm{Ub}$ moiety is handed over from the E1-Ub complex to the active C site of its UBC domain. An E3 ligase is responsible for the final reaction. It simultaneously interacts with the $\mathrm{E} 2-\mathrm{Ub}$ and a protein substrate, and ligates $\mathrm{Ub}$ with the protein through mediating isopeptide bond formation. Compared with E1s and E2s, E3s are most abundant. According to sequence properties and $\mathrm{Ub}$ conjugation mechanisms, E3s can be classified into three major groups, including Really Interesting New Gene (RING) domain-containing E3s, Homologous to E6-AP COOH terminus (HECT) domain-containing E3s and RING between RING (RBR) domain-containing E3s. RING domain-containing E3 family members do not need to form any intermediate thioester linkage with $\mathrm{Ub}$ but facilitate direct $\mathrm{Ub}$ transfer from E2s to substrates. In this step, they simply act as a scaffold to bring the E2-Ub to the vicinity of the substrate so that the $\varepsilon$-amino group of the substrate $\mathrm{K}$ residue can attack the thioester linkage of $\mathrm{E} 2-\mathrm{Ub}$ to form a transient tetrahedral complex. The E2 is then released after it catalyzes transfer of $\mathrm{Ub}$ to the substrate [51,52]. The RING-type E3s constitute the largest E3 family, all of 
which contain a conserved C-rich RING finger motif or RING finger-like domain, such as the plant homeodomain/leukemia-associated protein (PHD/LAP) finger motif and U box [46,53-55]. Of note, the activity of the RING finger and PHD/LAP motif, rather than the U box, require chelation of $\mathrm{Zn}^{2+}$ ions [56]. Distinctive from the RING-type E3s, HECT domain-containing E3s and RBR domain-containing E3s contain intrinsic enzymatic $\mathrm{C}$ site and adopt two-step reactions for $\mathrm{Ub}$ conjugation. Firstly, they accept the E2-Ub at their active $\mathrm{C}$ site to form an $\mathrm{E} 3-\mathrm{Ub}$ thioester conjugate. Next, $\mathrm{Ub}$ is transferred from the E3 to the substrate [46]. Beside the C-terminal HECT domain, the HECT-type E3s generally harbor a variable $\mathrm{N}$-terminal region responsible for specific substrate recognition [57]. According to sequence properties of N-terminal regions, the HECT-type E3s can be further grouped into three classes, respectively, the WW (two conserved tryptophans) domain-containing neuronal precursor cell-expressed developmentally downregulated 4 (Nedd4)/Nedd4-like E3s, HECT and regulator of chromosome condensation 1 (RCC1)-like domains (RLD)-containing (HERC) E3s, and other HECT-type E3s without WW and RLD domains [58]. Besides the WW domain, all Nedd4 family members harbor a C2 domain capable of binding with $\mathrm{Ca}^{2+}$ ions and phospholipids of intracellular membranes $[59,60]$. The WW domain is characterized by two conserved $W$ residues separated by a 20-22 amino acid interval. It can capture the proteins harboring either proline (P)-rich motif or phosphorylation signals at $S / T$ residues [61,62]. To date, nine Nedd4/Nedd4-like E3s have been identified in human cells, such as Smurfs and Wwp2 [63]. The HERC E3 group has six members. All of these ligases possess at least one RLD domain, which is characterized by seven repeats of 50-70 amino acids each [64]. The RBR-type E3s contain RING1 and RING2 domains [65]. The RING1 exhibit similar sequence properties with the canonical RING motif of RING-type E3s, and is responsible for binding with the E2-Ub intermediate. The RING2 domain contains a confirmed active $C$ site mediating $\mathrm{Ub}$ conjugation through a similar two-step mechanism with the HECT-type E3s [66]. To date, 13 RBR E3s, such as Parkin, have been annotated in human, most of which are not well studied.

\section{E3s-Mediated Regulation of Pluripotency Factors}

\subsection{Oct4}

Oct4 belongs to the Pit-Oct-Unc (POU) transcription factor family. It contains three major modules, including the conserved DNA-binding POU domain in the middle separating the two transactivation domains, respectively, at the $\mathrm{N}$ and $\mathrm{C}$ terminus [67-69]. The POU domain comprises two individual fragments capable of independent DNA association, namely POU-specific domain (POUs) and POU homeodomain (POUh) [70]. Besides DNA association, POU can also mediate the protein-protein interaction of Oct4 with other factors [68]. Oct4 expression can be detected as early as the zygote and cleavage stage [71]. It is subsequently restricted to the ICM, embryonic ectoderm, and primordial germ cells (PGCs) [71-75]. Oct4-null zygotes can bypass the cleavage stage but stall at the blastocyst stage due to impaired ICM, suggesting its critical role in pluripotency regulation [76,77]. In ESCs, Oct4 depletion impairs self-renewal and leads to cell differentiation into the trophectoderm lineage [1,78]. Strikingly, Oct 4 acts as the most efficient reprogramming factor since its overexpression alone can successfully achieve iPSC formation $[79,80]$. However, excessive Oct 4 is not favored by pluripotency maintenance. Two-fold induction of Oct4 results in ESC differentiation into primitive endoderm and mesoderm [78]. Therefore, pluripotency requires an appropriate dosage of Oct4.

Wwp2 is the first identified E3 capable of mediating Oct4 ubiquitination. It belongs to the Nedd4 ligase family and contains four WW domains separating a N-terminal C2 domain from the HECT catalytic domain at the $C$ terminus [81]. Wwp2 captures Oct4 for K63linked polyubiquitination through the WW domain both in human and mouse ESCs $[82,83]$. Although it is not clear whether $\mathrm{C} 2$ domain-mediated $\mathrm{Ca}^{2+}$ and phospholipid binding is involved in this modification, the $\mathrm{C} 2$ domain is demonstrated required by the enzymatic activity of the HECT domain [83]. Wwp2-mediated ubiquitination suppresses not only the stability but transcriptional activity of Oct4 [82-84]. Furthermore, WWP2 depletion 
increases the protein level of OCT4 in human ESCs [84]. However, this observation was not consistently reproduced by the study of Liao and Jin. They employed a similar strategy of short-hairpin RNA (shRNA) knockdown in human ESCs and found that OCT4 accumulation caused by WWP2 depletion can only be observed in differentiated ESCs with retinoid acid (RA) treatment, but not in the unperturbed counterpart cells [83]. Moreover, Wwop2-null mouse ESCs remain undifferentiated with a normal protein level of Oct4 [85]. In vitro ubiquitination assay combining mass spectrometry (MS) analysis identified five putative loci targeted by Wwp2-mediated modification in Oct4, including K118, K121, K133, K137, and K144 [85]. Mutation of all these five K residues does not alter Oct4 stability in undifferentiated mouse ESCs, but markedly enhances the capability of Oct4 in reprogramming [85]. Consistently, Wwp2 knockout increases the efficiency of Yamanaka factors-derived iPSC formation [85]. Therefore, Wwp2-mediated Oct4 ubiquitination appears dispensable for pluripotency maintenance but critical for cell fate determination and reprogramming.

The observation that Wwp2 depletion has no impact on Oct4 stability in ESCs suggests that multiple E3s could be coordinated to monitor Oct4 stability for robust maintenance of pluripotency. Itch is another Nedd4 family E3 capable of modifying Oct4 [86]. Similar to Wwp2, it contains one N-terminal C2 domain, four WW domains, and the C-terminal HECT domain [87]. It is ubiquitously expressed in most types of mammalian cells and involved in regulating various biological processes, such as immune response, differentiation, and tumorigenesis [88]. In ESCs, Itch and Wwp2 can both modify Oct4 with K63-linked poly-Ub chain for $26 \mathrm{~S}$ proteasome-mediated degradation, but do not share target residues $[83,86]$. The activity of Itch is inevitably required by pluripotency maintenance and acquisition since Itch depletion results in ESC differentiation and reduces the efficiency of iPSC formation [86]. At molecular level, although Itch-mediated ubiquitination promotes Oct4 degradation, this modification surprisingly enhances the affinity of Oct 4 binding with target genes and thus increases its transcriptional activity [86]. Therefore, the transcriptionally activating effect by Itch could overwrite its degradative activity toward Oct 4 in the process of pluripotency determination [86]. The Tripartite motif containing 32 (Trim32) belongs to the Trim-NHL family of RNA-binding proteins (RBPs) that are characterized by a three domain-containing module at the $\mathrm{N}$ terminus including one $\mathrm{N}$-terminal RING enzymatic domain, at least one B-box domain, and one coiled-coil motif [89-91]. The C-terminal NHL domain mediates the binding of Trim32 with other proteins or microRNAs [92]. Trim32 can mediate ubiquitination of Oct4. However, this modification-induced Oct4 degradation displays in a RING domain-independent manner, indicating that Trim32 might indirectly regulate Oct4 stability [93]. Trim32 expression is increased after mouse ESCs differentiate, and its deletion enhances iPSC formation and abolishes LIF withdrawal- or RA treatmentinduced iPSC differentiation [93]. PHD finger-containing E3 DPF2 is an interaction partner of Oct4 [94-96]. In human ESCs, it can assemble mixed polyubiquitin chains combining with K6, K48, and K63 linkages on OCT4, and promotes OCT4 proteasomal degradation [97]. Moreover, DPF2 appears involved in regulating the sub-nuclear localization of OCT4 [97]. However, whether the activity of DPF2 is required by pluripotency maintenance or iPSC formation is unknown.

\subsection{Sox2}

Sox2 contains a conserved HMG DNA-binding domain and a C-terminal transactivation domain $[98,99]$. In vivo, Sox 2 can be detected in the zygote and its expression maintains throughout the blastomere, blastocyst, and gastrulation stage [100]. Distinctive from the other two core ESC regulators, Oct4 and Nanog, Sox2 is also expressed in the extraembryonic ectoderm, fetal neural lineages, and adult stem cells, such as neural stem cells, retina, and pituitary progenitors [100-105]. Sox2 is indispensable for early embryo development and Sox2-null embryos cannot survive due to failure in normal epiblast formation [100]. Sox2 depletion in ESCs results in polyploidy formation and trophectoderm differentiation $[106,107]$. However, Sox2 elevation fails in reinforcing ESCs but leads to cell 
differentiation [106-108] As mentioned above, Oct4 similarly displays a dosage-dependent activity, implicating close relationship between these two factors. As expected, Sox2 and Oct4 always form a heterodimer to orchestrate the transcriptional regulatory network of ESCs [6,109]. Interestingly, the E3 of Oct4, Wwp2, is also able to ubiquitinate Sox2 for degradation [110]. Of note, ubiquitination closely crosstalks with methylation in the process of Sox 2 modification. For instance, Wwp2-mediated Ub conjugation depends on a methylation signal at Sox2-K119 in mouse ESCs [110]. What is more, monomethylated Sox2 at the K42 and K117 residues can be captured by a methyl-binding protein L3MBTL3, which further recruits the RING-type E3 DCAF5 to ubiquitinate the methylated Sox2 for proteolysis [111]. Unmethylated Sox2 is ubiquitinated by the anaphase-promoting complex/cyclosome (APC/C) [112]. The APC/C is a large E3 complex comprising nearly twenty subunits [113]. Among these subunits, RING-type E3 Apc11 and Apc2 form the catalytic center, whereas Apc10 facilitates substrate recognition [114]. In mouse ESCs, APC/C cooperates with ubiquitin-conjugating enzyme E2s (Ube2s) to modify Sox 2 with K11-linked poly- $\mathrm{Ub}$ chain at the K123 residue and thus destine it for 26S proteasomemediated degradation [112]. In this process, Ube2s and APC10 are both responsible for Sox2 recognition. Interestingly, although APC/C-Ube2s promotes Sox 2 degradation, Ube2s deletion does not drive ESCs to differentiate but reinforces the pluripotent state through inducing a set of pluripotency-related genes including Esrrb, Nanog, Lin28a, and Sall4 [112]. These genes can replace other combinations of Oct4, Sox2, Klf4, and c-Myc to efficiently support pluripotency [115]. APC/C-Ube2s-mediated ubiquitination seems not dependent on methylation at Sox2-K42, K119, or K117 since any mutation of these loci does not abolish APC/C-Ube2s-mediated Ub conjugation to Sox2 [112].

\subsection{Nanog}

Nanog is encoded by early embryo specific NK (ENK) that was initially identified in mouse ESCs. Compared with other NK protein family members, it shares low sequence similarity and is exclusively involved in ESC maintenance and embryonic development [116-118]. Its unique function depends on multiple domains, respectively, the serine-rich $\mathrm{N}$ terminus, the DNA-binding homeodomain, and the tryptophan repeat (WR)-containing $\mathrm{C}$ terminus. The $\mathrm{C}$ terminus comprises three sub-regions, including the $\mathrm{C}$-terminal activation domain 1 (CD1), the WR repeats in the middle, and the CD2 at the C-terminal end. The latter two sub-regions and the $\mathrm{N}$ terminus possess transactivation activity [119]. The expression of Nanog can be ubiquitously detected in all blastomeres, and is subsequently restricted to the ICM and the subsets of the epiblast cells including the primordial germ cells. It starts to decline during primitive streak formation $[116,117,120]$. Nanog-null embryos exhibit impaired ICM and die at 4.5 d.p.c due to failure in forming the primitive ectoderm [117]. Consistently, Nanog deletion results in ESC differentiation into endoderm lineages [116,117,121]. Conversely, Nanog overexpression confers ESCs resistance to exogenous induction of differentiation [116,117]. However, Nanog expression is not homozygous in ESCs under the serum culture condition, but stochastically fluctuates [122]. Although the Nanog-low ESCs can self-renew, they lose naïve pluripotency, failing in differentiation into germ lines [123]. K48- and K63-linked polyubiquitination are highly involved in monitoring the stability and activity of Nanog in ESCs [124]. To date, Skp1/Cul1/F-box (SCF)-like ligase complex SCF F-box and WD40 domain-containing protein 8 (Fbxw8) is the only E3 identified mediating Nanog ubiquitination [125]. F-box protein Fbxw8 exerts substrate recognition [126-129]. It coordinates with RING finger-containing RING box protein-1 (Rbx1), bridging protein Skp1 and scaffold protein Culin 7 (Cul7) to assemble the multi-subunit $\mathrm{SCF}^{\mathrm{Fbxw} 8}$ complex [130]. In mouse ESCs, $\mathrm{SCF}^{\mathrm{Fbxw8}}$-mediated ubiquitination of Nanog requires ERK1-activated phosphorylation signal. Moreover, Fbxw8 depletion results in Nanog accumulation, consequently enhancing self-renewal and preventing ESCs from differentiation [125]. In vivo, Fbxw8 deletion impairs embryo growth due to abnormal development of placenta [131,132]. However, it remains elusive whether Nanog acts as a dominant downstream effector of $\mathrm{SCF}^{\mathrm{Fbxw}}$ in the developmental process of embryos. Moreover, it will be of interest 
to uncover whether this ligase complex is involved in regulating naïve pluripotency or monitoring the fluctuating expression of Nanog in serum-cultured ESCs.

\subsection{C-Myc}

C-Myc oncoprotein belongs to the basic helix-loop-helix (bHLH) transcription factor superfamily, extensively involved in regulating cell metabolism, proliferation, differentiation, and apoptosis $[133,134]$. In mouse ESCs, c-Myc promotes self-renewal to support pluripotency and increase the efficiency of iPSC formation [31,135]. Although it preferentially binds with any open chromatin region without defined specificity for universal transcription activation, c-Myc possibly coordinates with Oct4, Sox2 and Nanog to selectively enhance transcription efficiency of ESC specific genes [136,137]. Of note, c-Myc acts distinctively in human ESCs since it fails in supporting self-renewal but promotes apoptosis and differentiation [138]. C-Myc harbors a short half-life rigorously regulated by ubiquitination $[139,140]$. The transactivation domain of c-Myc possesses two conserved Myc boxes (MBs), MB1 and MB2, providing binding loci for E3s [141,142]. Moreover, dual phosphorylation of MB1-T58/S62 residues promotes degradative ubiquitination of c-Myc, while S62 phosphorylation alone increases its stability instead [143,144]. Multiple E3s have been identified mediating ubiquitination of $\mathrm{c}-\mathrm{Myc}$, including $\mathrm{SCF}^{\mathrm{Skp} 2}$ ligase complex, $\mathrm{SCF}^{\mathrm{Fbxw7}}$ complex, and TRIM6 [145-148]. F-box proteins, Fbxw7 and Skp2, recognize the MB1 and MB2, respectively, to mediate degradative ubiquitination $[145,146,149]$. Importantly, Fbxw7-null embryos die at E10.5. Fbxw7 deletion results in c-Myc accumulation, which prevents mouse ESC differentiation [10]. Moreover, Fbxw7 deletion promotes iPS cell formation, which, however, cannot be reversed by $c-M y c$ depletion, indicating the existence of other substrates in the reprogramming process [10]. Another study by Egozi et al. explored the role of Skp2 in human ESCs. They demonstrated that high expression of Skp2 is co-related with the undifferentiated state of human ESCs. It selectively ubiquitinates cell cycle inhibitor p27, rather than c-Myc, for degradation to enhance proliferation and simultaneously prevent differentiation [150]. TRIM6 exerts important functions in pluripotency maintenance through ubiquitinating c-Myc independent of the phosphorylation signal at T58 and S62 residues [148]. Intriguingly, although TRIM6-depleted ESCs exhibit increased stability of c-Myc, TRIM6 elevation fails in reducing the stability of c-Myc but activates Nanog expression. Furthermore, TRIM6 manipulation-resulted Nanog elevation could not confer ESC independence of LIF signal, which appears inconsistent with the previous finding that elevated Nanog inhibits LIF withdrawal-induced ESC differentiation $[116,117]$. Trim32 may also be involved in ubiquitinating c-Myc in pluripotent cells [93]. The interplay between these two factors has been explored in neural stem cells [151-153].

\subsection{Krüppel-Like Factors (Klfs)}

Klfs belong to the zinc finger-containing transcription factor family and are characterized by three krüppel-like $\mathrm{C} 2 \mathrm{H} 2$ zinc finger DNA-binding domains. Although all Klfs have a similar DNA binding consensus, they function diversely through interacting with context-dependent partners via their variable $\mathrm{N}$-terminal region [154]. There are eighteen Klf proteins widely involved in the regulation of cell proliferation, differentiation, migration, inflammation, metabolism, and apoptosis [155]. Among these Klfs, only Klf2, Klf4, and Klf5 are sensitive to ESC differentiation [1,156]. They form a core Klf transcriptional regulatory circuitry maintaining self-renewal and pluripotency [156-158]. Under the LIF/serum culture condition, single or dual depletion among Klf2, Klf4, or Klf5 fails in driving ESC differentiation, but simultaneous triple knockdown of all these three genes results in loss of ESC identity [156]. However, under the 2i culture condition, naïve pluripotency of ESCs cannot be sustained after Klf2 deletion [159]. Moreover, Klf4 activation is essential to reprogram primed pluripotent mouse EpiSCs or human ESCs into naïve pluripotent cells $[160,161]$. Due to the critical roles of Klf2 and Klf4 in maintaining naïve pluripotency, they are selected as "naïve" factors [160,162]. Similar to Oct4, Sox2, and Nanog, Klf2 and Klf5 exhibit very short half-lives in ESCs (about $3 \mathrm{~h}$ ), which allow rapid response to any 
differentiation signals [163]. Interestingly, Klf4 is highly stable with a half-life of longer than $24 \mathrm{~h}$, and this high stability is markedly decreased upon differentiation, which requires a mono-Ub signal at its K249 residue [163]. ERK1/2-mediated phosphorylation at the S123 residue can also reduce the stability of Klf4. The phosphorylation mark allows E3 SCF ${ }^{\beta-T r C P}$ to capture Klf4 for polyubiquitination and proteasomal degradation, which subsequently results in ESC differentiation [164]. On the other hand, Klf4 transcriptionally activate the expression of membrane-associated ring finger (C3HC4) 5 (March5) to sustain its high stability. March5 is a RING-type E3 and located in the mitochondria membrane, regulating pluripotency, senescence, reactive oxygen species (ROS) generation and mitochondrial division [165-169]. In mouse ESCs, March5 acts as an indispensable factor for pluripotency maintenance. Furthermore, it can coordinate the four Yamanaka factors (Oct4, Sox2. Klf4 and c-Myc) to increase the efficiency of iPSC formation [165]. At the molecular level, March5 polyubiquitinates cAMP-dependent protein kinase type I-alpha regulatory subunit (Prkar1a) to activate protein kinase A (PKA), which finally results in the inhibition of the ERK signaling pathway [165]. ERK inhibition stalls Klf4-S123 phosphorylation-induced degradative ubiquitination by $\mathrm{SCF}^{\beta-\operatorname{TrCP}}$ and thus enhances Klf4 stability $[164,165]$. As expected, March5 can at least partially substitute for Klf4 to drive iPS cell formation [165].

\subsection{Epigenetic Regulators}

Pluripotent cells exhibit a unique epigenetic landscape, which is largely marked by histone modifications [170,171]. Compared with methylation and acetylation, information on correlation between histone ubiquitination and pluripotency is limited. Monoubiquitination of histone H2A-K119 and H2B-K120 has been relatively well documented. H2B-K120 monoubiquitination is mediated by a heterotetrameric E3 complex comprising Ring Finger Protein 20 (RNF20) and RNF40 [172]. This modification is always associated with transcription activation and is important for the differentiation process of ESCs, but not for ESC maintenance [173-175]. More recently, a study by Xie et al. demonstrated that RNF40 acts as a central mediator to promote pluripotency acquisition in the process of reprogramming [176]. Distinctive from H2B-K120 mono-Ub, H2A-K119 mono-Ub is correlated with transcription repression $[177,178]$. This signal can be mediated by RING-type E3 Ring1A/1B, and is critical for maintaining the undifferentiated state of ESCs. Double deletion of Ring1A and Ring1B results in ESC differentiation [179-183]. Another RING-type E3 Dzip3 can also mediate H2A-K119 monoubiquitination in ESCs and specifically acts at differentiation-related gene promoter regions through regulating $3 \mathrm{D}$ chromatin organization [184]. In addition to histone marks, a number of epigenetic regulators, such as Jarid2, Kdm3a, Hdac1, Dnmt3a, Jmjd1, Fbxo15, and Setdb1, display ubiquitination signals in ESCs $[10,185]$. However, the mechanisms underlying their ubiquitination and whether these signals are involved in regulating ESC identity remain elusive.

\section{Concluding Remarks and Perspectives}

Pluripotent ESCs and iPSCs exhibit unique transcriptomic, epigenomic, and proteomic signatures, which are precisely orchestrated by the interconnected regulatory network. Ubiquitination governs proteostasis and is one of the most abundant modification signals to monitor protein stability and activity. Therefore, ubiquitination is involved in nearly all protein-dependent cellular processes, including pluripotency maintenance and cell fate decision. In pluripotent ESCs, $\mathrm{Ub}$ /proteasome pathway-related genes are highly activated, and over one thousand proteins are marked by Ub signals [7-10]. Increasing studies identified pluripotency-related E3s through analyzing their interplay with core ESC regulators, such as Oct4, Sox2 and Nanog, and other pluripotency-related factors (Figure 1). For instance, ESC regulator Rex1 is ubiquitinated by E3 RNF12 for degradation, which activates X-chromosome inactivation of mouse ESCs [186]. Truncation mutation in RNF12 leads to loss of pluripotency and neuroectodermal differentiation [187]. These E3s appear tightly interconnected to form a pluripotency-specific ubiquitination network. For instance, Wwp2 can simultaneously ubiquitinate multiple substrates, Oct4, Sox2 and 
RNA polymerase II subunit B1 (Rpb1), in ESCs, which might efficiently reinforce the molecular signatures and network of pluripotency $[81,84,110]$. To further understand the ubiproteome in regulating pluripotency and reprogramming, questions remain to be investigated. For instance, how does ubiquitination dynamically regulate different states of pluripotency, such as naïve and primed states? How do E3 ligases coordinate with transcription factors and epigenetic regulators to prepare ESCs or iPSCs for an appropriate poised status during differentiation? Moreover, since ubiquitination always coexists with or requires other modification signals, how does it crosstalk with other types of modifications, such as methylation, acetylation, and phosphorylation, to globally orchestrate pluripotencyspecific molecular signatures. Answers to these questions will provide greater insights into our understanding of ESCs and iPSCs, and further their applications in basic and clinical research of human diseases. One of the technical challenges is to develop antibodies or Ub-based chemical probes to capture any Ub linkage of interest with high specificity and sensitivity [188].

Author Contributions: Y.W.: Figures, manuscript writing and final approval of manuscript; W.Z:: conception and design, financial support, manuscript writing and final approval of manuscript. All authors have read and agreed to the published version of the manuscript.

Funding: Our work is supported by NSFC fund (81872003) and Scientific Research Program of Beijing Education Commission (SQKM201810028010).

Acknowledgments: We apologize to the authors whose work could not be cited in this review due to space constraints. We appreciate the great work on ubiquitination from all of the past and present lab members. Our work is supported by NSFC fund (81872003) and Scientific Research Program of Beijing Education Commission (SQKM201810028010).

Conflicts of Interest: The authors declare no conflict of interest.

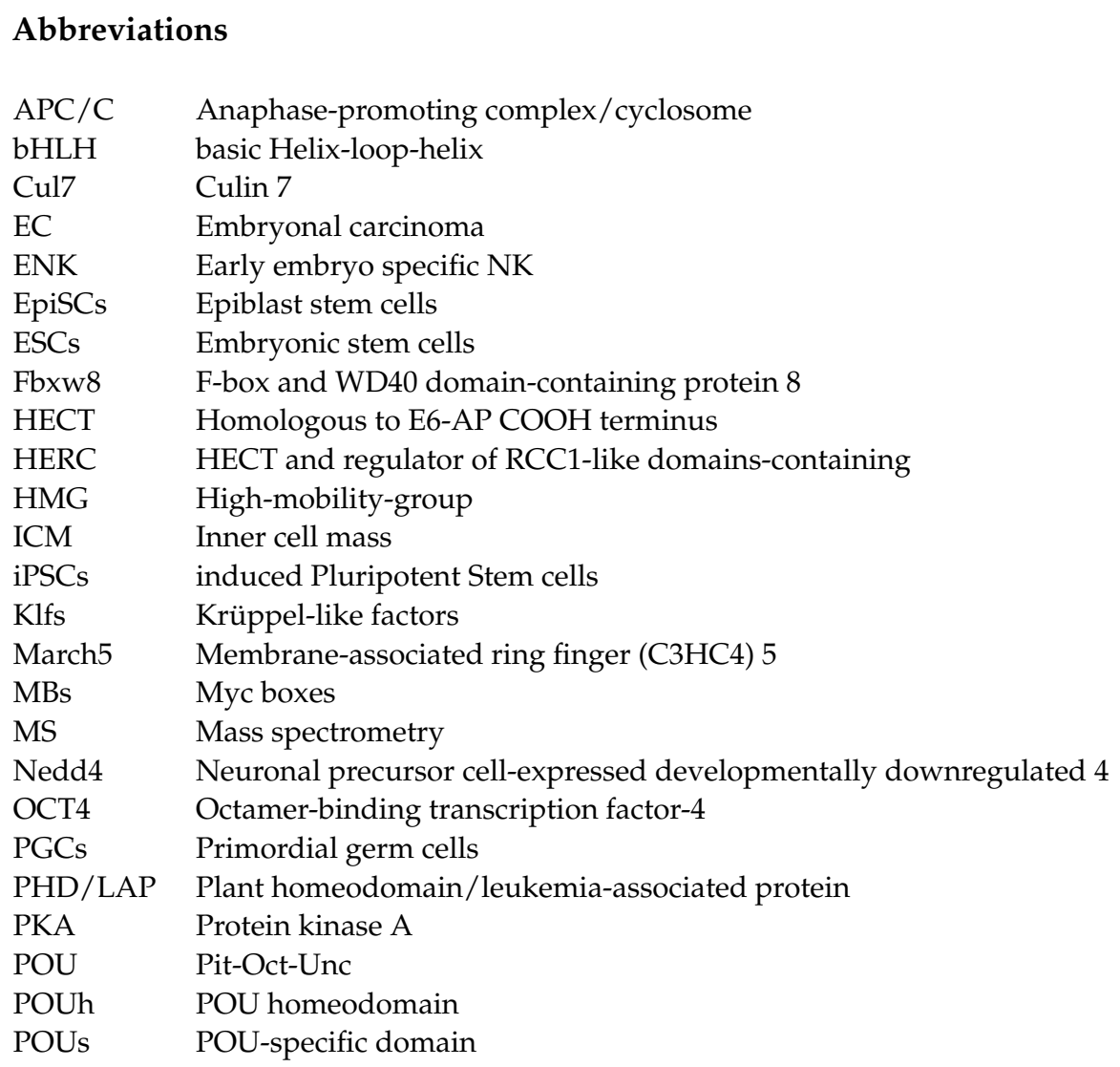




\begin{tabular}{ll} 
Prkar1a & Protein kinase type I-alpha \\
RA & Retinoid acid \\
RBPs & RNA-binding proteins \\
RBR & RING between RING \\
Rbx1 & RING box protein-1 \\
RCC1 & Regulator of chromosome condensation 1 \\
RING & Really Interesting New Gene \\
RLD & RCC1-like domains \\
RNF20 & Ring Finger Protein 20 \\
RNF40 & Ring Finger Protein 40 \\
ROS & Reactive oxygen species \\
Rpb1 & RNA polymerase II subunit B1 \\
SCF & Skp1/Cul1/F-box \\
shRNA & short-hairpin RNA \\
Sox2 & SRY-related HMG Box 2 \\
SRY & Sex-determining region Y \\
TFs & Transcription factors \\
TRIM32 & Tripartite motif containing 32 \\
Uba/E1 & Ub-activating enzyme \\
Ub-AMP & Ub-adenosine monophosphate \\
UBC/E2 & Ub-conjugating enzyme \\
Ube2s & Ubiquitin-conjugating enzyme E2s \\
Ub-G76 & Glycine 76 of Ub \\
WR & tryptophan repeat \\
WW & two conserved tryptophans \\
& \\
\hline bi
\end{tabular}

\section{References}

1. Ivanova, N.; Dobrin, R.; Lu, R.; Kotenko, I.; Levorse, J.; Decoste, C.; Schafer, X.; Lun, Y.; Lemischka, I.R. Dissecting self-renewal in stem cells with RNA interference. Nat. Cell Biol. 2006, 442, 533-538. [CrossRef]

2. Gökbuget, D.; Blelloch, R. Epigenetic control of transcriptional regulation in pluripotency and early differentiation. Development 2019, 146, dev164772. [CrossRef] [PubMed]

3. Li, M.; Belmonte, J.C.I. Ground rules of the pluripotency gene regulatory network. Nat. Rev. Genet. 2017, 18, 180-191. [CrossRef] [PubMed]

4. Martello, G.; Smith, A. The Nature of Embryonic Stem Cells. Annu. Rev. Cell Dev. Biol. 2014, 30, 647-675. [CrossRef]

5. De Los Angeles, A.; Ferrari, F.; Xi, R.; Fujiwara, Y.; Benvenisty, N.; Deng, H.; Hochedlinger, K.; Jaenisch, R.; Lee, S.; Leitch, H.G.; et al. Hallmarks of pluripotency. J. Nature 2015, 525, 469-478. [CrossRef] [PubMed]

6. Boyer, L.A.; Lee, T.I.; Cole, M.F.; Johnstone, S.E.; Levine, S.S.; Zucker, J.P.; Guenther, M.G.; Kumar, R.M.; Murray, H.L.; Jenner, R.G.; et al. Core Transcriptional Regulatory Circuitry in Human Embryonic Stem Cells. Cell 2005, 122, 947-956. [CrossRef] [PubMed]

7. Ramalho-Santos, M.; Yoon, S.; Matsuzaki, Y.; Mulligan, R.C.; Melton, D.A. "Stemness": Transcriptional Profiling of Embryonic and Adult Stem Cells. Science 2002, 298, 597-600. [CrossRef]

8. Baharvand, H.; Hajheidari, M.; Ashtiani, S.K.; Salekdeh, G.H. Proteomic signature of human embryonic stem cells. Proteomics 2006, 6, 3544-3549. [CrossRef]

9. Vilchez, D.; Boyer, L.; Morantte, I.; Lutz, M.; Merkwirth, C.; Joyce, D.; Spencer, B.; Page, L.; Masliah, E.; Berggren, W.T.; et al. Increased proteasome activity in human embryonic stem cells is regulated by PSMD11. Nat. Cell Biol. 2012, 489, 304-308. [CrossRef]

10. Buckley, S.M.; Aranda-Orgilles, B.; Strikoudis, A.; Apostolou, E.; Loizou, E.; Moran-Crusio, K.; Farnsworth, C.L.; Koller, A.A.; Dasgupta, R.; Silva, J.C.; et al. Regulation of Pluripotency and Cellular Reprogramming by the Ubiquitin-Proteasome System. Cell Stem Cell 2012, 11, 783-798. [CrossRef]

11. Selwood, L.; Johnson, M.H. Trophoblast and hypoblast in the monotreme, marsupial and eutherian mammal: Evolution and origins. BioEssays 2006, 28, 128-145. [CrossRef] [PubMed]

12. Nichols, J.; Smith, A. Naive and Primed Pluripotent States. Cell Stem Cell 2009, 4, 487-492. [CrossRef] [PubMed]

13. Wu, J.; Yamauchi, T.; Belmonte, J.C.I. An overview of mammalian pluripotency. Development 2016, 143, 1644-1648. [CrossRef] [PubMed]

14. Martin, G.R.; Evans, M.J. The morphology and growth of a pluripotent teratocarcinoma cell line and its derivatives in tissue culture. Cell 1974, 2, 163-172. [CrossRef]

15. Mintz, B.; Illmensee, K. Normal genetically mosaic mice produced from malignant teratocarcinoma cells. Proc. Natl. Acad. Sci. USA 1975, 72, 3585-3589. [CrossRef]

16. Papaioannou, V.E.; McBurney, M.W.; Gardner, R.L.; Evans, M.J. Fate of teratocarcinoma cells injected into early mouse embryos. Nat. Cell Biol. 1975, 258, 70-73. [CrossRef] 
17. Illmensee, K.; Mintz, B. Totipotency and normal differentiation of single teratocarcinoma cells cloned by injection into blastocysts. Proc. Natl. Acad. Sci. USA 1976, 73, 549-553. [CrossRef]

18. Papaioannou, V.E.; Gardner, R.L.; McBurney, M.W.; Babinet, C.; Evans, M.J. Participation of cultured teratocarcinoma cells in mouse embryogenesis. J. Embryol. Exp. Morphol. 1978, 44, 93-104.

19. Stewart, T.A.; Mintz, B. Successive generations of mice produced from an established culture line of euploid teratocarcinoma cells. Proc. Natl. Acad. Sci. USA 1981, 78, 6314-6318. [CrossRef]

20. Stewart, T.A.; Mintz, B. Recurrent germ-line transmission of the teratocarcinoma genome from the METT-1 culture line to progeny in vivo. J. Exp. Zool. 1982, 224, 465-469. [CrossRef]

21. Rossant, J.; McBurney, M.W. The developmental potential of a euploid male teratocarcinoma cell line after blastocyst injection. J. Embryol. Exp. Morphol. 1982, 70, 99-112. [PubMed]

22. Smith, A. Embryo-Derived Stem Cells: Of Mice and Men. Annu. Rev. Cell Dev. Biol. 2001, 17, 435-462. [CrossRef] [PubMed]

23. Evans, M.J.; Kaufman, M.H. Establishment in culture of pluripotential cells from mouse embryos. Nat. Cell Biol. 1981, 292, 154-156. [CrossRef]

24. Martin, G.R. Isolation of a pluripotent cell line from early mouse embryos cultured in medium conditioned by teratocarcinoma stem cells. Proc. Natl. Acad. Sci. USA 1981, 78, 7634-7638. [CrossRef] [PubMed]

25. Brons, I.G.M.; Smithers, L.E.; Trotter, M.W.B.; Rugg-Gunn, P.; Sun, B.; Lopes, S.M.C.D.S.; Howlett, S.K.; Clarkson, A.; AhrlundRichter, L.; Pedersen, R.A.; et al. Derivation of pluripotent epiblast stem cells from mammalian embryos. Nat. Cell Biol. 2007, 448, 191-195. [CrossRef] [PubMed]

26. Tesar, P.J.; Chenoweth, J.G.; Brook, F.A.; Davies, T.J.; Evans, E.P.; Mack, D.L.; Gardner, R.L.; McKay, R.D.G. New cell lines from mouse epiblast share defining features with human embryonic stem cells. Nat. Cell Biol. 2007, 448, 196-199. [CrossRef] [PubMed]

27. Ying, Q.-L.; Wray, J.; Nichols, J.; Batlle-Morera, L.; Doble, B.; Woodgett, J.; Cohen, P.; Smith, G. The ground state of embryonic stem cell self-renewal. Nat. Cell Biol. 2008, 453, 519-523. [CrossRef]

28. Yilmaz, A.; Benvenisty, N. Defining Human Pluripotency. Cell Stem Cell 2019, 25, 9-22. [CrossRef]

29. Thomson, J.A.; Itskovitz-Eldor, J.; Shapiro, S.S.; Waknitz, M.A.; Swiergiel, J.J.; Marshall, V.S.; Jones, J.M. Embryonic Stem Cell Lines Derived from Human Blastocysts. Science 1998, 282, 1145-1147. [CrossRef]

30. Reubinoff, B.E.; Pera, M.F.; Fong, C.-Y.; Trounson, A.; Bongso, A. Embryonic stem cell lines from human blastocysts: Somatic differentiation in vitro. Nat. Biotechnol. 2000, 18, 399-404. [CrossRef]

31. Takahashi, K.; Yamanaka, S. Induction of Pluripotent Stem Cells from Mouse Embryonic and Adult Fibroblast Cultures by Defined Factors. Cell 2006, 126, 663-676. [CrossRef] [PubMed]

32. Takahashi, K.; Tanabe, K.; Ohnuki, M.; Narita, M.; Ichisaka, T.; Tomoda, K.; Yamanaka, S. Induction of pluripotent stem cells from adult human fibroblasts by defined factors. Cell 2007, 131, 861-872. [CrossRef] [PubMed]

33. Yu, J.; Vodyanik, M.A.; Smuga-Otto, K.; Antosiewicz-Bourget, J.; Frane, J.L.; Tian, S.; Nie, J.; Jonsdottir, G.A.; Ruotti, V.; Stewart, R.; et al. Induced Pluripotent Stem Cell Lines Derived from Human Somatic Cells. Science 2007, 318, 1917-1920. [CrossRef] [PubMed]

34. Park, I.-H.; Zhao, R.; West, J.A.; Yabuuchi, A.; Huo, H.; Ince, T.A.; Lerou, P.H.; Lensch, M.W.; Daley, G.Q. Reprogramming of human somatic cells to pluripotency with defined factors. Nat. Cell Biol. 2007, 451, 141-146. [CrossRef] [PubMed]

35. Hershko, A.; Ciechanover, A. The ubiquitin system. Annu. Rev. Biochem. 1998, 67, 425-479. [CrossRef]

36. Wagner, S.A.; Beli, P.; Weinert, B.T.; Nielsen, M.L.; Cox, J.; Mann, M.; Choudhary, C. A Proteome-wide, Quantitative Survey of In Vivo Ubiquitylation Sites Reveals Widespread Regulatory Roles. Mol. Cell. Proteom. 2011, 10. [CrossRef]

37. Pickart, C.M. Mechanisms Underlying Ubiquitination. Annu. Rev. Biochem. 2001, 70, 503-533. [CrossRef]

38. Yau, R.; Rape, M. The increasing complexity of the ubiquitin code. Nat. Cell Biol. 2016, 18, 579-586. [CrossRef]

39. Vijay-Kumar, S.; Bugg, C.; Wilkinson, K.; Vierstra, R.; Hatfield, P.; Cook, W. Comparison of the three-dimensional structures of human, yeast, and oat ubiquitin. J. Biol. Chem. 1987, 262, 6396-6399. [CrossRef]

40. Aviel, S.; Winberg, G.; Massucci, M.; Ciechanover, A. Degradation of the Epstein-Barr Virus Latent Membrane Protein 1 (LMP1) by the Ubiquitin-Proteasome Pathway. J. Biol. Chem. 2000, 275, 23491-23499. [CrossRef]

41. Ciechanover, A.; Ben-Saadon, R. N-terminal ubiquitination: More protein substrates join in. Trends Cell Biol. 2004, 14, 103-106. [CrossRef] [PubMed]

42. Breitschopf, K.; Bengal, E.; Ziv, T.; Admon, A.; Ciechanover, A. A novel site for ubiquitination: The N-terminal residue, and not internal lysines of MyoD, is essential for conjugation and degradation of the protein. EMBO J. 1998, 17, 5964-5973. [CrossRef] [PubMed]

43. Cadwell, K.; Coscoy, L. Ubiquitination on nonlysine residues by a viral E3 ubiquitin ligase. Science 2005, 309, 127-130. [CrossRef] [PubMed]

44. Bhogaraju, S.; Kalayil, S.; Liu, Y.; Bonn, F.; Colby, T.; Matic, I.; Dikic, I. Phosphoribosylation of Ubiquitin Promotes Serine Ubiquitination and Impairs Conventional Ubiquitination. Cell 2016, 167, 1636-1649.e13. [CrossRef] [PubMed]

45. Komander, D.; Rape, M. The Ubiquitin Code. Annu. Rev. Biochem. 2012, 81, 203-229. [CrossRef]

46. Wenzel, D.M.; Klevit, R.E. Following Ariadne's thread: A new perspective on RBR ubiquitin ligases. BMC Biol. 2012, 10, 24. [CrossRef]

47. Ohtake, F.; Saeki, Y.; Ishido, S.; Kanno, J.; Tanaka, K. The K48-K63 Branched Ubiquitin Chain Regulates NF-кB Signaling. Mol. Cell 2016, 64, 251-266. [CrossRef] 
48. Emmerich, C.H.; Ordureau, A.; Strickson, S.; Arthur, J.S.; Pedrioli, P.G.; Komander, D.; Cohen, P. Activation of the canonical IKK complex by K63/M1-linked hybrid ubiquitin chains. Proc. Natl. Acad. Sci. USA 2013, 110, 15247-15252. [CrossRef]

49. Boname, J.M.; Thomas, M.; Stagg, H.R.; Xu, P.; Peng, J.; Lehner, P.J. Efficient Internalization of MHC I Requires Lysine-11 and Lysine-63 Mixed Linkage Polyubiquitin Chains. Traffic 2010, 11, 210-220. [CrossRef]

50. Hann, Z.S.; Ji, C.; Olsen, S.K.; Lu, X.; Lux, M.C.; Tan, D.S.; Lima, C.D. Structural basis for adenylation and thioester bond formation in the ubiquitin E1. Proc. Natl. Acad. Sci. USA 2019, 116, 15475-15484. [CrossRef]

51. Passmore, L.A.; Barford, D. Getting into position: The catalytic mechanisms of protein ubiquitylation. Biochem. J. 2004, 379, 513-525. [CrossRef] [PubMed]

52. Pickart, C.M.; Eddins, M.J. Ubiquitin: Structures, functions, mechanisms. Biochim. Biophys. Acta (BBA) Bioenerg. 2004, 1695, 55-72. [CrossRef] [PubMed]

53. Morreale, F.E.; Walden, H. Types of Ubiquitin Ligases. Cell 2016, 165, 248-248.e1. [CrossRef] [PubMed]

54. Dul, B.E.; Walworth, N.C. The Plant Homeodomain Fingers of Fission Yeast Msc1 Exhibit E3 Ubiquitin Ligase Activity. J. Biol. Chem. 2007, 282, 18397-18406. [CrossRef]

55. Ivanov, A.V.; Peng, H.; Yurchenko, V.; Yap, K.L.; Negorev, D.G.; Schultz, D.C.; Psulkowski, E.; Fredericks, W.J.; White, D.E.; Maul, G.G.; et al. PHD Domain-Mediated E3 Ligase Activity Directs Intramolecular Sumoylation of an Adjacent Bromodomain Required for Gene Silencing. Mol. Cell 2007, 28, 823-837. [CrossRef]

56. Metzger, M.B.; Pruneda, J.N.; Klevit, R.E.; Weissman, A.M. RING-type E3 ligases: Master manipulators of E2 ubiquitin-conjugating enzymes and ubiquitination. Biochim. Biophys. Acta (BBA) Bioenerg. 2014, 1843, 47-60. [CrossRef]

57. Rotin, D.; Kumar, S. Physiological functions of the HECT family of ubiquitin ligases. Nat. Rev. Mol. Cell Biol. 2009, 10, 398-409. [CrossRef]

58. Wang, Y.; Argiles-Castillo, D.; Kane, E.I.; Zhou, A.; Spratt, D.E. HECT E3 ubiquitin ligases—Emerging insights into their biological roles and disease relevance. J. Cell Sci. 2020, 133, jcs228072. [CrossRef]

59. Dunn, R.; Klos, D.A.; Adler, A.S.; Hicke, L. The C2 domain of the Rsp5 ubiquitin ligase binds membrane phosphoinositides and directs ubiquitination of endosomal cargo. J. Cell Biol. 2004, 165, 135-144. [CrossRef]

60. Huibregtse, J.M.; Scheffner, M.; Beaudenon, S.; Howley, P.M. A family of proteins structurally and functionally related to the E6-AP ubiquitin-protein ligase. Proc. Natl. Acad. Sci. USA 1995, 92, 2563-2567. [CrossRef]

61. Chen, H.I.; Sudol, M. The WW domain of Yes-associated protein binds a proline-rich ligand that differs from the consensus established for Src homology 3-binding modules. Proc. Natl. Acad. Sci. USA 1995, 92, 7819-7823. [CrossRef] [PubMed]

62. Lu, P.J.; Zhou, X.Z.; Shen, M.; Lu, K.P. Function of WW domains as phosphoserine- or phosphothreonine-binding modules. Science 1999, 283, 1325-1328. [CrossRef] [PubMed]

63. Bork, P.; Sudol, M. The WW domain: A signalling site in dystrophin? Trends Biochem. Sci. 1994, 19, 531-533. [CrossRef]

64. Scheffner, M.; Kumar, S. Mammalian HECT ubiquitin-protein ligases: Biological and pathophysiological aspects. Biochim. Biophys. Acta (BBA) Bioenerg. 2014, 1843, 61-74. [CrossRef] [PubMed]

65. Eisenhaber, B.; Chumak, N.; Eisenhaber, F.; Hauser, M.-T. The ring between ring fingers (RBR) protein family. Genome Biol. 2007, 8, 209. [CrossRef]

66. Dove, K.K.; Klevit, R.E. RING-Between-RING E3 Ligases: Emerging Themes amid the Variations. J. Mol. Biol. 2017, 429, 3363-3375. [CrossRef]

67. Vigano, M.A.; Staudt, L.M. Transcriptional activation by Oct-3: Evidence for a specific role of the POU-specific domain in mediating functional interaction with Oct-1. Nucleic Acids Res. 1996, 24, 2112-2118. [CrossRef]

68. Brehm, A.; Ohbo, K.; Schöler, H.R. The carboxy-terminal transactivation domain of Oct-4 acquires cell specificity through the POU domain. Mol. Cell. Biol. 1997, 17, 154-162. [CrossRef]

69. Lim, H.-Y.; Do, H.-J.; Lee, W.-Y.; Kim, D.-K.; Seo, H.G.; Chung, H.-J.; Park, J.-K.; Chang, W.-K.; Kim, J.-H.; Kim, J. Implication of human OCT4 transactivation domains for self-regulatory transcription. Biochem. Biophys. Res. Commun. 2009, 385, 148-153. [CrossRef]

70. Esch, D.; Vahokoski, J.; Groves, M.R.; Pogenberg, V.; Cojocaru, V.; Bruch, H.V.; Han, D.; Drexler, H.C.A.; Araúzo-Bravo, M.J.; $\mathrm{Ng}$, C.K.L.; et al. A unique Oct4 interface is crucial for reprogramming to pluripotency. Nat. Cell Biol. 2013, 15, 295-301. [CrossRef]

71. Schöler, H.R. Octamania: The POU factors in murine development. Trends Genet. 1991, 7, 323-329. [CrossRef]

72. Okamoto, K.; Okazawa, H.; Okuda, A.; Sakai, M.; Muramatsu, M.; Hamada, H. A novel octamer binding transcription factor is differentially expressed in mouse embryonic cells. Cell 1990, 60, 461-472. [CrossRef]

73. Schöler, H.; Hatzopoulos, A.; Balling, R.; Suzuki, N.; Gruss, P. A family of octamer-specific proteins present during mouse embryogenesis: Evidence for germline-specific expression of an Oct factor. EMBO J. 1989, 8, 2543-25500. [CrossRef] [PubMed]

74. Rosner, M.H.; Vigano, M.A.; Ozato, K.; Timmons, P.M.; Poirie, F.; Rigby, P.W.J.; Staudt, L.M. A POU-domain transcription factor in early stem cells and germ cells of the mammalian embryo. Nat. Cell Biol. 1990, 345, 686-692. [CrossRef] [PubMed]

75. Palmieri, S.L.; Peter, W.; Hess, H.; Schöler, H.R. Oct-4 Transcription Factor Is Differentially Expressed in the Mouse Embryo during Establishment of the First Two Extraembryonic Cell Lineages Involved in Implantation. Dev. Biol. 1994, 166, $259-267$. [CrossRef]

76. Nichols, J.; Zevnik, B.; Anastassiadis, K.; Niwa, H.; Klewe-Nebenius, D.; Chambers, I.; Schöler, H.; Smith, A. Formation of Pluripotent Stem Cells in the Mammalian Embryo Depends on the POU Transcription Factor Oct4. Cell 1998, 95, 379-391. [CrossRef] 
77. Le Bin, G.C.; Muñoz-Descalzo, S.; Kurowski, A.; Leitch, H.; Lou, X.; Mansfield, W.; Etienne-Dumeau, C.; Grabole, N.; Mulas, C.; Niwa, H.; et al. Oct4 is required for lineage priming in the developing inner cell mass of the mouse blastocyst. Development 2014, 141, 1001-1010. [CrossRef]

78. Niwa, H.; Miyazaki, J.; Smith, A.G. Quantitative expression of Oct-3/4 defines differentiation, dedifferentiation or self-renewal of ES cells. Nat. Genet. 2000, 24, 372-376. [CrossRef]

79. Wu, T.; Wang, H.; He, J.; Kang, L.; Jiang, Y.; Liu, J.; Zhang, Y.; Kou, Z.; Liu, L.; Zhang, X.; et al. Reprogramming of Trophoblast Stem Cells into Pluripotent Stem Cells by Oct4. Stem Cells 2011, 29, 755-763. [CrossRef]

80. Tsai, S.-Y.; Bouwman, B.A.; Ang, Y.-S.; Kim, S.J.; Lee, D.-F.; Lemischka, I.R.; Rendl, M. Single Transcription Factor Reprogramming of Hair Follicle Dermal Papilla Cells to Induced Pluripotent Stem Cells. Stem Cells 2011, 29, 964-971. [CrossRef]

81. Li, H.; Zhang, Z.; Wang, B.; Zhang, J.; Zhao, Y.; Jin, Y. Wwp2-Mediated Ubiquitination of the RNA Polymerase II Large Subunit in Mouse Embryonic Pluripotent Stem Cells. Mol. Cell. Biol. 2007, 27, 5296-5305. [CrossRef] [PubMed]

82. Xu, H.M.; Liao, B.; Zhang, Q.J.; Wang, B.B.; Li, H.; Zhong, X.-M.; Sheng, H.Z.; Zhao, Y.M.; Jin, Y. Wwp2, an E3 Ubiquitin Ligase That Targets Transcription Factor Oct-4 for Ubiquitination. J. Biol. Chem. 2004, 279, 23495-23503. [CrossRef] [PubMed]

83. Liao, B.; Jin, Y. Wwp2 mediates Oct4 ubiquitination and its own auto-ubiquitination in a dosage-dependent manner. Cell Res. 2009, 20, 332-344. [CrossRef] [PubMed]

84. Xu, H.; Wang, W.; Li, C.; Yu, H.; Yang, A.; Wang, B.; Jin, Y. WWP2 promotes degradation of transcription factor OCT4 in human embryonic stem cells. Cell Res. 2009, 19, 561-573. [CrossRef] [PubMed]

85. Li, S.; Xiao, F.; Zhang, J.; Sun, X.; Wang, H.; Zeng, Y.; Hu, J.; Tang, F.; Gu, J.; Zhao, Y.; et al. Disruption of OCT4 Ubiquitination Increases OCT4 Protein Stability and ASH2L-B-Mediated H3K4 Methylation Promoting Pluripotency Acquisition. Stem Cell Rep. 2018, 11, 973-987. [CrossRef]

86. Liao, B.; Zhong, X.; Xu, H.; Xiao, F.; Fang, Z.; Gu, J.; Chen, Y.; Zhao, Y.; Jin, Y. Itch, an E3 ligase of Oct4, is required for embryonic stem cell self-renewal and pluripotency induction. J. Cell. Physiol. 2013, 228, 1443-1451. [CrossRef]

87. Aki, D.; Li, Q.; Li, H.; Liu, Y.-C.; Lee, J.H. Immune regulation by protein ubiquitination: Roles of the E3 ligases VHL and Itch. Protein Cell 2019, 10, 395-404. [CrossRef]

88. Aki, D.; Zhang, W.; Liu, Y.-C. The E3 ligase Itch in immune regulation and beyond. Immunol. Rev. 2015, 266, 6-26. [CrossRef]

89. Napolitano, L.M.; Jaffray, E.G.; Hay, R.T.; Meroni, G. Functional interactions between ubiquitin E2 enzymes and TRIM proteins. Biochem. J. 2011, 434, 309-319. [CrossRef]

90. Meroni, G.; Diez-Roux, G. TRIM/RBCC, a novel class of 'single protein RING finger' E3 ubiquitin ligases. BioEssays 2005, 27, 1147-1157. [CrossRef]

91. Lazzari, E.; Meroni, G. TRIM32 ubiquitin E3 ligase, one enzyme for several pathologies: From muscular dystrophy to tumours Int. J. Biochem. Cell Biol. 2016, 79, 469-477. [CrossRef] [PubMed]

92. Schwamborn, J.C.; Berezikov, E.; Knoblich, J.A. The TRIM-NHL Protein TRIM32 Activates MicroRNAs and Prevents Self-Renewal in Mouse Neural Progenitors. Cell 2009, 136, 913-925. [CrossRef] [PubMed]

93. Bahnassawy, L.; Perumal, T.; Gonzalez-Cano, L.; Hillje, A.-L.; Taher, L.; Makałowski, W.; Suzuki, Y.; Fuellen, G.; Del Sol, A.; Schwamborn, J.C. TRIM32 modulates pluripotency entry and exit by directly regulating Oct4 stability. Sci. Rep. 2015, 5, 13456. [CrossRef] [PubMed]

94. Pardo, M.; Lang, B.; Yu, L.; Prosser, H.; Bradley, A.; Babu, M.M.; Choudhary, J.S. An Expanded Oct4 Interaction Network: Implications for Stem Cell Biology, Development, and Disease. Cell Stem Cell 2010, 6, 382-395. [CrossRef] [PubMed]

95. Wang, J.; Rao, S.; Chu, J.; Shen, X.; Levasseur, D.N.; Theunissen, T.W.; Orkin, S.H. A protein interaction network for pluripotency of embryonic stem cells. Nature 2006, 444, 364-368. [CrossRef] [PubMed]

96. Van den Berg, D.L.; Snoek, T.; Mullin, N.P.; Yates, A.; Bezstarosti, K.; Demmers, J.; Chambers, I.; Poot, R.A. An Oct4-centered protein interaction network in embryonic stem cells. Cell Stem Cell 2010, 6, 369-381. [CrossRef] [PubMed]

97. Liu, C.; Zhang, D.; Shen, Y.; Tao, X.; Liu, L.; Zhong, Y.; Fang, S. DPF2 regulates OCT4 protein level and nuclear distribution. Biochim. Biophys. Acta 2015, 1853, 3279-3293. [CrossRef]

98. Gubbay, J.; Collignon, J.; Koopman, P.; Capel, B.; Economou, A.; Münsterberg, A.; Vivian, N.; Goodfellow, P.; Lovell-Badge, R. A gene mapping to the sex-determining region of the mouse $\mathrm{Y}$ chromosome is a member of a novel family of embryonically expressed genes. Nat. Cell Biol. 1990, 346, 245-250. [CrossRef]

99. Novak, D.; Hüser, L.; Elton, J.J.; Umansky, V.; Altevogt, P.; Utikal, J. SOX2 in development and cancer biology. Semin. Cancer Biol. 2020, 67, 74-82. [CrossRef]

100. Avilion, A.A.; Nicolis, S.K.; Pevny, L.H.; Perez, L.; Vivian, N.; Lovell-Badge, R. Multipotent cell lineages in early mouse development depend on SOX2 function. Genes Dev. 2003, 17, 126-140. [CrossRef]

101. Wood, H.B.; Episkopou, V. Comparative expression of the mouse Sox1, Sox2 and Sox3 genes from pre-gastrulation to early somite stages. Mech. Dev. 1999, 86, 197-201. [CrossRef]

102. Yabuta, Y.; Kurimoto, K.; Ohinata, Y.; Seki, Y.; Saitou, M. Gene Expression Dynamics During Germline Specification in Mice Identified by Quantitative Single-Cell Gene Expression Profiling1. Biol. Reprod. 2006, 75, 705-716. [CrossRef] [PubMed]

103. Cavallaro, M.; Mariani, J.; Lancini, C.; Latorre, E.; Caccia, R.; Gullo, F.; Valotta, M.; DeBiasi, S.; Spinardi, L.; Ronchi, A.; et al. Impaired generation of mature neurons by neural stem cells from hypomorphic Sox 2 mutants. Development 2008, 135, 541-557. [CrossRef] [PubMed] 
104. Cimadamore, F.; Fishwick, K.; Giusto, E.; Gnedeva, K.; Cattarossi, G.; Miller, A.; Pluchino, S.; Brill, L.M.; Bronner, M.; Terskikh, A.V. Human ESC-derived neural crest model reveals a key role for SOX2 in sensory neurogenesis. Cell Stem Cell 2011, 8, 538-551. [CrossRef]

105. Fauquier, T.; Rizzoti, K.; Dattani, M.; Lovell-Badge, R.; Robinson, I.C.A.F. SOX2-expressing progenitor cells generate all of the major cell types in the adult mouse pituitary gland. Proc. Natl. Acad. Sci. USA 2008, 105, 2907-2912. [CrossRef]

106. Chew, J.-L.; Loh, Y.-H.; Zhang, W.; Chen, X.; Tam, W.-L.; Yeap, L.-S.; Li, P.; Ang, Y.-S.; Lim, B.; Robson, P.; et al. Reciprocal Transcriptional Regulation of Pouff1 and Sox2 via the Oct4/Sox2 Complex in Embryonic Stem Cells. Mol. Cell. Biol. 2005, 25, 6031-6046. [CrossRef]

107. Li, J.; Pan, G.; Cui, K.; Liu, Y.; Xu, S.; Pei, D. A Dominant-negative Form of Mouse SOX2 Induces Trophectoderm Differentiation and Progressive Polyploidy in Mouse Embryonic Stem Cells. J. Biol. Chem. 2007, 282, 19481-19492. [CrossRef]

108. Kopp, J.L.; Ormsbee, B.D.; Desler, M.; Rizzino, A. Small Increases in the Level of Sox2 Trigger the Differentiation of Mouse Embryonic Stem Cells. Stem Cells 2008, 26, 903-911. [CrossRef]

109. Chen, X.; Xu, H.; Yuan, P.; Fang, F.; Huss, M.; Vega, V.B.; Wong, E.; Orlov, Y.L.; Zhang, W.; Jiang, J.; et al. Integration of External Signaling Pathways with the Core Transcriptional Network in Embryonic Stem Cells. Cell 2008, 133, 1106-1117. [CrossRef]

110. Fang, L.; Zhang, L.; Wei, W.; Jin, X.; Wang, P.; Tong, Y.; Li, J.; Du, J.X.; Wong, J. A Methylation-Phosphorylation Switch Determines Sox2 Stability and Function in ESC Maintenance or Differentiation. Mol. Cell 2014, 55, 537-551. [CrossRef]

111. Zhang, C.; Leng, F.; Saxena, L.; Hoang, N.; Yu, J.; Alejo, S.; Lee, L.; Qi, D.; Lu, F.; Sun, H.; et al. Proteolysis of methylated SOX2 protein is regulated by L3MBTL3 and CRL4DCAF5 ubiquitin ligase. J. Biol. Chem. 2019, 294, 476-489. [CrossRef] [PubMed]

112. Wang, J.; Zhang, Y.; Hou, J.; Qian, X.; Zhang, H.; Zhang, Z.; Li, M.; Wang, R.; Liao, K.; Wang, Y.; et al. Ube2s regulates Sox2 stability and mouse ES cell maintenance. Cell Death Differ. 2015, 23, 393-404. [CrossRef] [PubMed]

113. Peters, J.-M. The anaphase promoting complex/cyclosome: A machine designed to destroy. Nat. Rev. Mol. Cell Biol. 2006, 7, 644-656. [CrossRef] [PubMed]

114. Chang, L.-F.; Zhang, Z.; Yang, J.; McLaughlin, S.H.; Barford, D. Molecular architecture and mechanism of the anaphase-promoting complex. Nat. Cell Biol. 2014, 513, 388-393. [CrossRef]

115. Buganim, Y.; Faddah, D.A.; Cheng, A.W.; Itskovich, E.; Markoulaki, S.; Ganz, K.; Klemm, S.L.; Van Oudenaarden, A.; Jaenisch, R. Single-Cell Expression Analyses during Cellular Reprogramming Reveal an Early Stochastic and a Late Hierarchic Phase. Cell 2012, 150, 1209-1222. [CrossRef]

116. Chambers, I.; Colby, D.; Robertson, M.; Nichols, J.; Lee, S.; Tweedie, S.; Smith, A. Functional Expression Cloning of Nanog, a Pluripotency Sustaining Factor in Embryonic Stem Cells. Cell 2003, 113, 643-655. [CrossRef]

117. Mitsui, K.; Tokuzawa, Y.; Itoh, H.; Segawa, K.; Murakami, M.; Takahashi, K.; Maruyama, M.; Maeda, M.; Yamanaka, S. The Homeoprotein Nanog Is Required for Maintenance of Pluripotency in Mouse Epiblast and ES Cells. Cell 2003, 113, 631-642. [CrossRef]

118. Silva, J.C.R.; Nichols, J.; Theunissen, T.W.; Guo, G.; Van Oosten, A.L.; Barrandon, O.; Wray, J.; Yamanaka, S.; Chambers, I.; Smith, A. Nanog Is the Gateway to the Pluripotent Ground State. Cell 2009, 138, 722-737. [CrossRef]

119. Pan, G.J.; Pei, D.Q. Identification of two distinct transactivation domains in the pluripotency sustaining factor nanog. Cell Res. 2003, 13, 499-502. [CrossRef]

120. Hart, A.H.; Hartley, L.; Ibrahim, M.; Robb, L. Identification, cloning and expression analysis of the pluripotency promoting Nanog genes in mouse and human. Dev. Dyn. 2004, 230, 187-198. [CrossRef]

121. Hatano, S.-Y.; Tada, M.; Kimura, H.; Yamaguchi, S.; Kono, T.; Nakano, T.; Suemori, H.; Nakatsuji, N.; Tada, T. Pluripotential competence of cells associated with Nanog activity. Mech. Dev. 2005, 122, 67-79. [CrossRef] [PubMed]

122. Chambers, I.; Silva, J.; Colby, D.; Nichols, J.; Nijmeijer, B.; Robertson, M.; Vrana, J.; Jones, K.L.; Grotewold, L.; Smith, A. Nanog safeguards pluripotency and mediates germline development. Nat. Cell Biol. 2007, 450, 1230-1234. [CrossRef] [PubMed]

123. Chickarmane, V.; Olariu, V.; Peterson, C. Probing the role of stochasticity in a model of the embryonic stem cell-Heterogeneous gene expression and reprogramming efficiency. BMC Syst. Biol. 2012, 6, 98. [CrossRef] [PubMed]

124. Ramakrishna, S.; Suresh, R.; Lim, K.-H.; Cha, B.-H.; Lee, S.-H.; Kim, K.-S.; Baek, K.-H. PEST Motif Sequence Regulating Human NANOG for Proteasomal Degradation. Stem Cells Dev. 2011, 20, 1511-1519. [CrossRef] [PubMed]

125. Kim, S.-H.; Kim, M.O.; Cho, Y.-Y.; Yao, K.; Kim, D.J.; Jeong, C.-H.; Yu, D.H.; Bae, K.B.; Cho, E.J.; Jung, S.K.; et al. ERK1 phosphorylates Nanog to regulate protein stability and stem cell self-renewal. Stem Cell Res. 2014, 13, 1-11. [CrossRef]

126. Elledge, S.J.; Harper, J.W. The role of protein stability in the cell cycle and cancer. Biochim. Biophys. Acta (BBA) Bioenerg. 1998, 1377, M61-M70. [CrossRef]

127. Kamura, T.; Koepp, D.M.; Conrad, M.N.; Skowyra, D.; Moreland, R.J.; Iliopoulos, O.; Lane, W.S.; Kaelin, W.G., Jr.; Elledge, S.J.; Conaway, R.C.; et al. Rbx1, a Component of the VHL Tumor Suppressor Complex and SCF Ubiquitin Ligase. Sci. 1999, 284, 657-661. [CrossRef]

128. Ohta, T.; Michel, J.J.; Schottelius, A.J.; Xiong, Y. ROC1, a Homolog of APC11, Represents a Family of Cullin Partners with an Associated Ubiquitin Ligase Activity. Mol. Cell 1999, 3, 535-541. [CrossRef]

129. Seol, J.H.; Feldman, R.R.; Zachariae, W.; Shevchenko, A.; Correll, C.C.; Lyapina, S.; Chi, Y.; Galova, M.; Claypool, J.; Sandmeyer, S.; et al. Cdc53/cullin and the essential Hrt1 RING-H2 subunit of SCF define a ubiquitin ligase module that activates the E2 enzyme Cdc34. Genes Dev. 1999, 13, 1614-1626. [CrossRef] 
130. Arai, T.; Kasper, J.S.; Skaar, J.R.; Ali, S.H.; Takahashi, C.; DeCaprio, J.A. Targeted disruption of $p 185 / C u l 7$ gene results in abnormal vascular morphogenesis. Proc. Natl. Acad. Sci. USA 2003, 100, 9855-9860. [CrossRef]

131. Lin, P.; Fu, J.; Zhao, B.; Lin, F.; Zou, H.; Liu, L.; Zhu, C.; Wang, H.; Yu, X. Fbxw8 is involved in the proliferation of human choriocarcinoma JEG-3 cells. Mol. Biol. Rep. 2011, 38, 1741-1747. [CrossRef] [PubMed]

132. Tsunematsu, R.; Nishiyama, M.; Kotoshiba, S.; Saiga, T.; Kamura, T.; Nakayama, K.I. Fbxw8 Is Essential for Cul1-Cul7 Complex Formation and for Placental Development. Mol. Cell. Biol. 2006, 26, 6157-6169. [CrossRef] [PubMed]

133. Dang, C.V. MYC, Metabolism, Cell Growth, and Tumorigenesis. Cold Spring Harb. Perspect. Med. 2013, 3, a014217. [CrossRef] [PubMed]

134. Bretones, G.; Delgado, M.D.; León, J. Myc and cell cycle control. Biochim. Biophys. Acta (BBA) Bioenerg. 2015, 1849, 506-516. [CrossRef] [PubMed]

135. Cartwright, P.; McLean, C.; Sheppard, A.; Rivett, D.; Jones, K.; Dalton, S. LIF/STAT3 controls ES cell self-renewal and pluripotency by a Myc-dependent mechanism. Development 2005, 132, 885-896. [CrossRef]

136. Nie, Z.; Hu, G.; Wei, G.; Cui, K.; Yamane, A.; Resch, W.; Wang, R.; Green, D.R.; Tessarollo, L.; Casellas, R.; et al. c-Myc Is a Universal Amplifier of Expressed Genes in Lymphocytes and Embryonic Stem Cells. Cell 2012, 151, 68-79. [CrossRef]

137. Young, R.A. Control of the Embryonic Stem Cell State. Cell 2011, 144, 940-954. [CrossRef]

138. Sumi, T.; Tsuneyoshi, N.; Nakatsuji, N.; Suemori, H. Apoptosis and differentiation of human embryonic stem cells induced by sustained activation of c-Myc. Oncogene 2007, 26, 5564-5576. [CrossRef]

139. Farrell, A.S.; Sears, R.C. MYC Degradation. Cold Spring Harb. Perspect. Med. 2014, 4, a014365. [CrossRef]

140. Hann, S.R.; Eisenman, R.N. Proteins encoded by the human c-myc oncogene: Differential expression in neoplastic cells. Mol. Cell. Biol. 1984, 4, 2486-2497. [CrossRef]

141. Sun, X.X.; He, X.; Yin, L.; Komada, M.; Sears, R.C.; Dai, M.S. The nucleolar ubiquitin-specific protease USP36 deubiquitinates and stabilizes c-Myc. Proc. Natl. Acad. Sci. USA 2015, 112, 3734-3739. [CrossRef] [PubMed]

142. Flinn, E.M.; Busch, C.M.C.; Wright, A.P.H. myc Boxes, Which Are Conserved in myc Family Proteins, Are Signals for Protein Degradation via the Proteasome. Mol. Cell. Biol. 1998, 18, 5961-5969. [CrossRef] [PubMed]

143. Sears, R.; Leone, G.; DeGregori, J.; Nevins, J.R. Ras Enhances Myc Protein Stability. Mol. Cell 1999, 3, 169-179. [CrossRef]

144. Sears, R.; Nuckolls, F.; Haura, E.; Taya, Y.; Tamai, K.; Nevins, J.R. Multiple Ras-dependent phosphorylation pathways regulate Myc protein stability. Genes Dev. 2000, 14, 2501-2514. [CrossRef] [PubMed]

145. Kim, S.Y.; Herbst, A.; Tworkowski, K.A.; Salghetti, S.E.; Tansey, W.P. Skp2 Regulates Myc Protein Stability and Activity. Mol. Cell 2003, 11, 1177-1188. [CrossRef]

146. Yada, M.; Hatakeyama, S.; Kamura, T.; Nishiyama, M.; Tsunematsu, R.; Imaki, H.; Ishida, N.; Okumura, F.; Nakayama, K.; Nakayama, K.I. Phosphorylation-dependent degradation of c-Myc is mediated by the F-box protein Fbw7. EMBO J. 2004, 23, 2116-2125. [CrossRef] [PubMed]

147. Welcker, M.; Orian, A.; Jin, J.; Grim, J.A.; Harper, J.W.; Eisenman, R.N.; Clurman, B.E. The Fbw7 tumor suppressor regulates glycogen synthase kinase 3 phosphorylation-dependent c-Myc protein degradation. Proc. Natl. Acad. Sci. USA 2004, 101, 9085-9090. [CrossRef]

148. Sato, T.; Okumura, F.; Ariga, T.; Hatakeyama, S. TRIM6 interacts with Myc and maintains the pluripotency of mouse embryonic stem cells. J. Cell Sci. 2012, 125, 1544-1555. [CrossRef]

149. Von der Lehr, N.; Johansson, S.; Wu, S.; Bahram, F.; Castell, A.; Cetinkaya, C.; Hydbring, P.; Weidung, I.; Nakayama, K.; Nakayama, K.I.; et al. The F-box protein Skp2 participates in c-Myc proteosomal degradation and acts as a cofactor for c-Myc-regulated transcription. Mol. Cell 2003, 11, 1189-1200. [CrossRef]

150. Egozi, D.; Shapira, M.; Paor, G.; Ben-Izhak, O.; Skorecki, K.; Hershko, D.D. Regulation of the cell cycle inhibitor p27 and its ubiquitin ligase Skp2 in differentiation of human embryonic stem cells. FASEB J. 2007, 21, 2807-2817. [CrossRef]

151. Hillje, A.L.; Worlitzer, M.M.; Palm, T.; Schwamborn, J.C. Neural stem cells maintain their stemness through protein kinase C $\zeta$-mediated inhibition of TRIM32. Stem Cells 2011, 29, 1437-1447. [PubMed]

152. Fults, D.; Pedone, C.; Dai, C.; Holland, E.C. MYC Expression Promotes the Proliferation of Neural Progenitor Cells in Culture and In Vivo. Neoplasia 2002, 4, 32-39. [CrossRef] [PubMed]

153. Ke, Y.; Zhang, E.E.; Hagihara, K.; Wu, D.; Pang, Y.; Klein, R.; Curran, T.; Ranscht, B.; Feng, G.-S. Deletion of Shp2 in the Brain Leads to Defective Proliferation and Differentiation in Neural Stem Cells and Early Postnatal Lethality. Mol. Cell. Biol. 2007, 27, 6706-6717. [CrossRef] [PubMed]

154. Oishi, Y.; Manabe, I. Krüppel-Like Factors in Metabolic Homeostasis and Cardiometabolic Disease. Front. Cardiovasc. Med. 2018, 5, 69. [CrossRef]

155. Pearson, R.; Fleetwood, J.; Eaton, S.; Crossley, M.; Bao, S. Krüppel-like transcription factors: A functional family. Int. J. Biochem. Cell Biol. 2008, 40, 1996-2001. [CrossRef]

156. Jiang, J.; Chan, Y.-S.; Loh, Y.-H.; Cai, J.; Tong, G.-Q.; Lim, C.-A.; Robson, P.R.H.; Zhong, S.; Ng, H.-H. A core Klf circuitry regulates self-renewal of embryonic stem cells. Nat. Cell Biol. 2008, 10, 353-360. [CrossRef]

157. Zhang, P.; Andrianakos, R.; Yang, Y.; Liu, C.; Lu, W. Kruppel-like Factor 4 (Klf4) Prevents Embryonic Stem (ES) Cell Differentiation by Regulating Nanog Gene Expression*. J. Biol. Chem. 2010, 285, 9180-9189. [CrossRef]

158. Aksoy, I.; Giudice, V.; Delahaye, E.; Wianny, F.; Aubry, M.; Mure, M.; Chen, J.; Jauch, R.; Bogu, G.K.; Nolden, T.; et al. Klf4 and Klf5 differentially inhibit mesoderm and endoderm differentiation in embryonic stem cells. Nat. Commun. 2014, 5, 3719. [CrossRef] 
159. Yeo, J.-C.; Jiang, J.; Tan, Z.-Y.; Yim, G.-R.; Göke, J.; Kraus, P.; Liang, H.; Gonzales, K.A.U.; Chong, H.-C.; Tan, C.-P.; et al. Klf2 Is an Essential Factor that Sustains Ground State Pluripotency. Cell Stem Cell 2014, 14, 864-872. [CrossRef]

160. Guo, G.; Yang, J.; Nichols, J.; Hall, J.S.; Eyres, I.; Mansfield, W.; Smith, A. Klf4 reverts developmentally programmed restriction of ground state pluripotency. Development 2009, 136, 1063-1069. [CrossRef]

161. Hanna, J.H.; Cheng, A.W.; Saha, K.; Kim, J.; Lengner, C.J.; Soldner, F.; Cassady, J.P.; Muffat, J.; Carey, B.W.; Jaenisch, R. Human embryonic stem cells with biological and epigenetic characteristics similar to those of mouse ESCs. Proc. Natl. Acad. Sci. USA 2010, 107, 9222-9227. [CrossRef] [PubMed]

162. Dunn, S.-J.; Martello, G.; Yordanov, B.; Emmott, S.; Smith, A. Defining an essential transcription factor program for naive pluripotency. Science 2014, 344, 1156-1160. [CrossRef] [PubMed]

163. Dhaliwal, N.K.; Abatti, L.E.; Mitchell, J.A. KLF4 protein stability regulated by interaction with pluripotency transcription factors overrides transcriptional control. Genes Dev. 2019, 33, 1069-1082. [CrossRef] [PubMed]

164. Kim, M.O.; Kim, S.-H.; Cho, Y.-Y.; Nadas, J.; Jeong, C.-H.; Yao, K.; Kim, D.J.; Yu, D.-H.; Keum, Y.-S.; Lee, K.-Y.; et al. ERK1 and ERK2 regulate embryonic stem cell self-renewal through phosphorylation of Klf4. Nat. Struct. Mol. Biol. 2012, 19, 283-290. [CrossRef]

165. Gu, H.; Li, Q.; Huang, S.; Lu, W.; Cheng, F.; Gao, P.; Wang, C.; Miao, L.; Mei, Y.; Wu, M. Mitochondrial E3 ligase March5 maintains stemness of mouse ES cells via suppression of ERK signalling. Nat. Commun. 2015, 6, 7112. [CrossRef]

166. Yonashiro, R.; Sugiura, A.; Miyachi, M.; Fukuda, T.; Matsushita, N.; Inatome, R.; Ogata, Y.; Suzuki, T.; Dohmae, N.; Yanagi, S Mitochondrial Ubiquitin Ligase MITOL Ubiquitinates Mutant SOD1 and Attenuates Mutant SOD1-induced Reactive Oxygen Species Generation. Mol. Biol. Cell 2009, 20, 4524-4530. [CrossRef]

167. Karbowski, M.; Neutzner, A.; Youle, R.J. The mitochondrial E3 ubiquitin ligase MARCH5 is required for Drp1 dependent mitochondrial division. J. Cell Biol. 2007, 178, 71-84. [CrossRef]

168. Park, Y.-Y.; Lee, S.; Karbowski, M.; Neutzner, A.; Youle, R.J.; Cho, H. Loss of MARCH5 mitochondrial E3 ubiquitin ligase induces cellular senescence through dynamin-related protein 1 and mitofusin 1. J. Cell Sci. 2010, 123, 619-626. [CrossRef]

169. Shi, H.-X.; Liu, X.; Wang, Q.; Tang, P.; Liu, X.-Y.; Shan, Y.-F.; Wang, C. Mitochondrial Ubiquitin Ligase MARCH5 Promotes TLR7 Signaling by Attenuating TANK Action. PLoS Pathog. 2011, 7, e1002057. [CrossRef]

170. Mattout, A.; Meshorer, E. Chromatin plasticity and genome organization in pluripotent embryonic stem cells. Curr. Opin. Cell Biol. 2010, 22, 334-341. [CrossRef]

171. Bernstein, B.E.; Mikkelsen, T.S.; Xie, X.; Kamal, M.; Huebert, D.J.; Cuff, J.; Fry, B.; Meissner, A.; Wernig, M.; Plath, K.; et al. A Bivalent Chromatin Structure Marks Key Developmental Genes in Embryonic Stem Cells. Cell 2006, 125, 315-326. [CrossRef] [PubMed]

172. Zhu, B.; Zheng, Y.; Pham, A.-D.; Mandal, S.S.; Erdjument-Bromage, H.; Tempst, P.; Reinberg, D. Monoubiquitination of Human Histone H2B: The Factors Involved and Their Roles in HOX Gene Regulation. Mol. Cell 2005, 20, 601-611. [CrossRef] [PubMed]

173. Henry, K.W.; Wyce, A.; Lo, W.-S.; Duggan, L.J.; Emre, N.T.; Kao, C.-F.; Pillus, L.; Shilatifard, A.; Osley, M.A.; Berger, S.L. Transcriptional activation via sequential histone H2B ubiquitylation and deubiquitylation, mediated by SAGA-associated Ubp8. Genes Dev. 2003, 17, 2648-2663. [CrossRef] [PubMed]

174. Kao, C.-F.; Hillyer, C.; Tsukuda, T.; Henry, K.; Berger, S.L.; Osley, M.A. Rad6 plays a role in transcriptional activation through ubiquitylation of histone H2B. Genes Dev. 2004, 18, 184-195. [CrossRef]

175. Fuchs, G.; Shema, E.; Vesterman, R.; Kotler, E.; Wolchinsky, Z.; Wilder, S.; Golomb, L.; Pribluda, A.; Zhang, F.; Haj-Yahya, M.; et al. RNF20 and USP44 regulate stem cell differentiation by modulating H2B monoubiquitylation. Mol. Cell 2012, 46, 662-673. [CrossRef]

176. Xie, W.; Miehe, M.; Laufer, S.; Johnsen, S.A. The H2B ubiquitin-protein ligase RNF40 is required for somatic cell reprogramming. Cell Death Dis. 2020, 11, 287. [CrossRef]

177. Zhou, W.; Zhu, P.; Wang, J.; Pascual, G.; Ohgi, K.A.; Lozach, J.; Glass, C.K.; Rosenfeld, M.G. Histone H2A Monoubiquitination Represses Transcription by Inhibiting RNA Polymerase II Transcriptional Elongation. Mol. Cell 2008, 29, 69-80. [CrossRef]

178. Nakagawa, T.; Kajitani, T.; Togo, S.; Masuko, N.; Ohdan, H.; Hishikawa, Y.; Koji, T.; Matsuyama, T.; Ikura, T.; Muramatsu, M.; et al. Deubiquitylation of histone H2A activates transcriptional initiation via trans-histone cross-talk with H3K4 di- and trimethylation. Genes Dev. 2008, 22, 37-49. [CrossRef]

179. Endoh, M.; Endo, T.A.; Endoh, T.; Fujimura, Y.-I.; Ohara, O.; Toyoda, T.; Otte, A.P.; Okano, M.; Brockdorff, N.; Vidal, M.; et al. Polycomb group proteins Ring1A/B are functionally linked to the core transcriptional regulatory circuitry to maintain ES cell identity. Development 2008, 135, 1513-1524. [CrossRef]

180. Wang, H.; Wang, L.; Erdjument-Bromage, H.; Vidal, M.; Tempst, P.; Jones, R.S.; Zhang, Y. Role of histone H2A ubiquitination in Polycomb silencing. Nat. Cell Biol. 2004, 431, 873-878. [CrossRef]

181. De Napoles, M.; Mermoud, J.E.; Wakao, R.; Tang, Y.A.; Endoh, M.; Appanah, R.; Nesterova, T.B.; Silva, J.; Otte, A.P.; Vidal, M.; et al. Polycomb group proteins Ring1A/B link ubiquitylation of histone $\mathrm{H} 2 \mathrm{~A}$ to heritable gene silencing and $\mathrm{X}$ inactivation. Dev. Cell 2004, 7, 663-676. [CrossRef] [PubMed]

182. Stock, J.K.; Giadrossi, S.; Casanova, M.; Brookes, E.; Vidal, M.; Koseki, H.; Brockdorff, N.; Fisher, A.G.; Pombo, A. Ring1-mediated ubiquitination of H2A restrains poised RNA polymerase II at bivalent genes in mouse ES cells. Nat. Cell Biol. 2007, 9, 1428-1435. [CrossRef] [PubMed] 
183. Van der Stoop, P.; Boutsma, E.A.; Hulsman, D.; Noback, S.; Heimerikx, M.; Kerkhoven, R.M.; Voncken, J.W.; Wessels, L.F.; van Lohuizen, M. Ubiquitin E3 ligase Ring1b/Rnf2 of polycomb repressive complex 1 contributes to stable maintenance of mouse embryonic stem cells. PLOS ONE 2008, 3, e2235. [CrossRef]

184. Inoue, D.; Aihara, H.; Sato, T.; Mizusaki, H.; Doiguchi, M.; Higashi, M.; Imamura, Y.; Yoneda, M.; Miyanishi, T.; Fujii, S.; et al. Dzip3 regulates developmental genes in mouse embryonic stem cells by reorganizing 3D chromatin conformation. Sci. Rep. 2015, 5, 16567. [CrossRef] [PubMed]

185. Okita, Y.; Nakayama, K.I. UPS delivers pluripotency. Cell Stem Cell 2012, 11, 728-730. [CrossRef]

186. Gontan, C.; Achame, E.M.; Demmers, J.; Barakat, T.S.; Rentmeester, E.; Van Ijcken, W.; Grootegoed, J.A.; Gribnau, J. RNF12 initiates X-chromosome inactivation by targeting REX1 for degradation. Nat. Cell Biol. 2012, 485, 386-390. [CrossRef]

187. Bustos, F.; Segarra-Fas, A.; Chaugule, V.K.; Brandenburg, L.; Branigan, E.; Toth, R.; Macartney, T.; Knebel, A.; Hay, R.T.; Walden, H.; et al. RNF12 X-Linked Intellectual Disability Mutations Disrupt E3 Ligase Activity and Neural Differentiation. Cell Rep. 2018, 23, 1599-1611. [CrossRef]

188. Sui, X.; Wang, Y.; Du, Y.-X.; Liang, L.-J.; Zheng, Q.; Li, Y.-M.; Liu, L. Development and application of ubiquitin-based chemical probes. Chem. Sci. 2020, 11, 12633-12646. [CrossRef] 